\title{
DISCURSO DO PROFESSOR OSCAR MARTINS GOMES
}

"Ainda sob a forte impressão que no meu espírito deixou a grande solenidade de anteontem na Reitoria da Universidade, sob a presidência do Magnífico Reitor Theodócio Atherino, quando recebi, das mãos do eminente professor Diretor José Munhoz de Melo, o título, sumamente honroso, de Professor Emérito, é com emoção, das maiores já por mim experimentadas na minha vida, que, na presente cerimônia, me vejo distinguido ainda com esta homenagem na sede da antiga Faculdade de Direito, da mesma Universidade.

Observo que, na perenidade do bronze, ficou fixada aquela expressiva data, de 1913, quando, imbuido de fé juvenil no magno empreendimento, me matriculei no primeiro ano, integrando assim a turma pioneira.

Ainda na placa está lançada a data de 1945, quando ingressei no corpo docente da mesma Faculdade, início da minha carreira. assás dignificante, de professor. 
E, em seguida, o registro deste ano, assinalando a outorga do alto título de Professor Emérito.

De modo que, assim, em meio à consideração de meus colegas professores, antigos e atuais, alunos e ex-alunos, não sei mais o que poderia esperar nesta minha vida, que já vai longa.

$\mathrm{Na}$ primeira sede modestíssima, da rua Comendador Araujo, em antigo sobradinho, recentemente tombado como monumento histórico, inclusive com meu voto, como membro do Conselho do Patrimônio Histórico e Artístico, recebemos nós, os componentes da primeira turma, ensinamentos dos currículos da época, no primeiro, e no segundo ano.

Em seguida passamos para este edifício, construído em linhas soberbas, nas quais se destacava uma grande cúpula. Era apenas a parte central da construção, onde sempre, desde então até hoje, tem funcionado a escola de Direito.

Sobrevieram os notáveis aumentos para maior capacidade, e ainda a colunata greco-romana, com a escadaria externa, do que resultou o imponente monumento arquitetônico onde ora nos encontramos, servindo também aos demais cursos, que constituem a conceituada Universidade Federal do Paraná.

Nesta oportunidade, tão expressiva para mim, quero mencionar, como especial homenagem, os nomes dos colegas do curso, que - concluiram já falecidos, dos quais me lembro: Leônidas Moura de Loiola, Antonio Leopoldo do Santos Filho, Lauro Neri do Canto, Luiz Gonzaga de Quadros, Hugo Antonio de Barros, Samuel Cesar de Oliveira, João Teófilo Gomi Júnior, Generoso Borges, Manoel Pereira de Macedo, João Soares Barcelos, Gastão da Costa Faria. Aristoxenes Correia de Bittencourt, Izaura Sidney Gasparini, Tasso da Silveira e Oscar Joseph De Plácido e Silva, que foi o primeiro aluno matriculado na Universidade e a honrou sobremaneira, mais tarde, como autor de substanciais e importantes livros jurídicos, divulgados em todo o país.

Da mencionada turma de 1913 somos três sobrev:ventes: eu, Oscar Borges de Macedo, ex-Secretário de Estado e ex-Prefeito de Curitiba, e J.C. de A.ndrade Muricy, escritor de alta nomeada no país, ainda recentemente distinguido pelo valioso conjunto de suas obras, com o Prêmio Machado de Assis, pela Academia Brasileira de Letras.

Considero ainda de justiça e ato de reconhecimento e apreço, recordar os professores daquele modesto mas produtivo pri- 
meiro quinquênio do curso, os beneméritos cooperadores que trabalhavam gratuitamente, Azevedo Macedo, Pânfilo de Assunção, Benjamin Lins, Vieira de Alencar, Otávio do Amaral, Vieira Cavalcanti, Marins Camargo, Hugo Simas, José Amadeu Cesar, Euclides Bevilacqua, Alencar Piedade, Pinheiro Lima, Antonio Victor de Sá Barreto e outros cujos nomes talvez agora não me ocorram.

A Universidade fundara-se sob o regime livre, isto é, desoficializado, que fora instituido, como novidade, pela lei orgânica do ensino, de 1911. Nova lei posterior, oficializando novamente o ensino superior, trouxe à novel instituição grandes dificuldades, que ela foi aos poucos vencendo, até vir a constituir o notável monumento de hoje.

Não vou reproduzir agora outros tantos informes e referências que já mencionei na minha oração de anteontem na Reitoria.

Quero, entretanto, ainda e finalmente, manifestar minha jubilosa gratidão ante a grande e imorredoura homenagem que este bronze representa para mim, bem assim meus agradecimentos aos meus amigos e colegas do corpo docente e do corpo discente, professores e alunos, mui especialmente os professores Munhoz de Melo e Gaspar Lacerda Pinto, respectivamente Diretor e Vice-Diretor do Setor de Cincias Sociais Aplicadas, no qual se integra o atual Curso de Direito.

Ainda: ao meu querido colega e amigo professor Henrique Lenz Cesar, que, com tanta eficiência e brilho, me sucedeu na cátedra de Direito Internacional Privado, quero dizer de minha gratidão pela sua belíssima oração, agora, não obstante exagerando, bondosamente, meus méritos. 